\title{
Allergenic fungal spores in the air of urban parks
}

\author{
Idalia Kasprzyk (iD) Agnieszka Grinn-Gofroń • Agata Ćwik • Katarzyna Kluska • \\ Paloma Cariñanos · Tomasz Wójcik
}

Received: 28 January 2020/ Accepted: 27 October 2020/Published online: 11 November 2020

(C) The Author(s) 2020

\begin{abstract}
Urban green spaces, especially urban parks, are essential for the proper functioning of cities, but they can be a serious source of airborne fungal spores. Aerobiological monitoring was carried out in urban parks of different typology to estimate the risk associated with fungal spores for citizens. Volumetric method was applied with the use of portable Burkard Sampler. In the air of the studied parks, the most dominant spores are strong allergenic or considered as potentially allergenic. Cladosporium spores were found in enormous concentrations in all studied parks, and it affected the low biodiversity of fungal spores in the parks. Compared to Cladosporium, concentrations of Alternaria spores in the air
\end{abstract}

I. Kasprzyk $(\bowtie) \cdot$ K. Kluska

Department of Environmental Monitoring, College of Natural Sciences, University of Rzeszów, Zelwerowicza 4, 35-601 Rzeszów, Poland

e-mail: idalia@univ.rzeszow.pl

A. Grinn-Gofroń

Department of Plant Taxonomy and Phytogeography, Faculty of Biology, University of Szczecin, Waska 13, 71-415 Szczecin, Poland

\section{A. Ćwik · T. Wójcik}

Department of Nature Conservation and Landscape Ecology, College of Natural Sciences, University of Rzeszów, Zelwerowicza 4, 35-601 Rzeszów, Poland

P. Cariñanos

Department of Botany, Faculty of Pharmacy, Campus de Cartuja, University of Granada, 18071 Granada, Spain were several dozen times lower, but still a risk for people who are allergic. The fungal spores spectra and their seasonal occurrence in each park were similar. The highest similarities in the patterns of the season were found in the case of Cladosporium, Alternaria, Epicoccum, and the lowest in the case of Torula and Drechslera type. Due to the fact that allergy sufferers are most often polysensitized, the period when they should limit long visits in the urban parks is JulyAugust, when the concentration of allergenic fungal spores of many taxa is the highest.

Keywords Aerobiology · Allergy · Biological air pollutants · Fungal spores · Urban ecosystem disservices · Urban parks

\section{Introduction}

Fungal spores are considered as one of the most important aeroallergens, causing adverse health effects. Among the various allergenic fungal spores, aerobiological surveys report Alternaria as the most prevalent airborne fungal type and an important aeroallergen (Budd 1986; Mitakakis et al. 2001). Cladosporium is frequently reported as the most abundant aeroallergen and as the second most allergenic fungal type worldwide (Tariq et al. 1996; Knutsen et al. 2012). Both fungal spore types can be responsible for hospital admissions due to severe 
asthma attacks in sensitized individuals, with a prevalence among children and with symptoms sometimes manifested as acute respiratory failure (Dales et al. 2000; Bush and Prochnau 2004; Lee and Liao 2014). Asthma is a chronic disease of the airways characterized by recurrent attacks of breathlessness and wheezing, which vary in severity and frequency from person to person (To et al. 2012; WHO 2019). Apart from these two spore types, others are indicated as potential cause of allergies. Studies from various parts of the world have clearly implicated Ganoderma spores as aeroallergens (Hasnain et al. 2004), and they have been implicated in the elicitation of respiratory allergic diseases. Nonetheless, the airborne basidiospores have been ignored in many studies, yet high concentrations of basidiospores exist in the atmosphere at various locations around the world (Levetin 1991; Grinn-Gofron 2010). Some species of Epicoccum produce highly allergenic spores, reaching their peak in early autumn. It can trigger high cutaneous reactivities, sharing allergenicity with different fungi responsible for the allergic type I symptomatology (Bisht et al. 2004). Drechslera type strong positive reactions have been documented in cutaneous testes in atopic individuals. Another study that took place at the Anderson Cancer Center (USA) described this genera as one of the etiologic agents of 16 cases of fungal allergic sinusitis in a population of patients between 8 and 71 years, with a mean of 25 years (Chew et al. 2000). The other taxa, such as Curvularia, Botrytis, Ganoderma, are considered as potentially allergen and may be a causative agent of human infections (SimonNobbe et al. 2008). Several fungi allergens represent cross-reactivity what was confirmed by the study on the sequence identity of A. alternata, Aureobasidium pullulans, Aspergillus fumigatus and $C$. herbarum allergens (Twaroch et al. 2016). Many fungal species cause IgE-mediated type I allergic reactions. Other clinical syndromes are: bronchopulmonary mycoses, allergic sinusitis, hypersensitivity pneumonitis. Additionally, the mycotoxins occurring in spores and mycelia cause immunosuppression (Simon-Nobbe et al. 2008).

It was stated that Cladosporium herbarum and Alternaria alternata might be the third most common aeroallergens (after house dust and grass pollen) (Simon-Nobbe et al. 2008 and references therein). Therefore, it is very important to assess the potential risks of the atmospheric presence of fungal spores. In
2004, Beggs has reviewed the need for more research on fungal spores; however, little has been done since then. There are indications that changing climate may lead to alterations in phenology, and the dynamics of fungal communities has provided relevant evidence that specific fungal taxa could be vulnerable to global environmental change (Damialis et al. 2015).

From a socio-economic perspective, the healthrelated implications due to airborne fungal spores are also very important. Asthma, lung diseases and allergies are a common respiratory disease, observed in up to $30 \%$ of the adult European population (Masoli et al. 2004; Singh and Mathur 2012). This percentage has been reported to have increased dramatically and is expected to rise even more over the following decades (Singh and Mathur 2012). Selgrade et al. (2006) have reported that approximately 300 million people suffer from asthma symptoms worldwide and that 13.2 million emergency visits to health practitioners and about 4000 deaths related to asthma incidents are annually recorded. If one takes into account that respiratory allergic diseases (i.e. asthma) have increased in frequency, it is challenging even to re-calculate the heath- and cost-effects of allergies on human health currently and in the future climate projections.

Numerous data on the incidence of illness and economic effects encourage detailed research. It is known that in inhalant allergy treatment it is crucial to recognition the cause of the disease and to know the possibility of avoiding contact with an allergen. It is also important to elaborate effective forecasts regarding the occurrence and concentration of aeroallergens in the air. Currently, large areas of vegetation such as forests and agricultural lands, in particular large-scale crops, are considered as a main source of airborne fungal spores (Skjøth et al. 2016). However, the majority of the human population live in urban areas (Seto et al. 2011) and contact with such regions is not frequent. This does not mean that the concentration of fungal spores in the air does not pose a serious threat to people. Greenery is a key element in city structure, it occupies an increasing area and is perceived as a positive element in its space-urban ecosystem services (Ćwik et al. 2018). However, more and more studies show the negative effects of vegetation on city dwellers, including those who are allergic-urban ecosystem disservices (Kasprzyk et al. 2019b). Scientific research mainly focuses on urban parks as a 
source of allergenic pollen, but the health impact that the presence of spores in these environments may have is less considered (Konijnendijk 2018). It is known that the production of fungal spores is clearly higher than pollen grain; therefore, it was assumed that in urban parks the concentrations of the former in the air could be higher because vegetation is one of the priority substrates for fungal development. There is no detailed research on this problem and in order to fill the knowledge gap, aerobiological monitoring was carried out in urban parks of different typologies to assess the degree of risk to park visitors from allergic fungal spores. The thesis regarding the spatial variation in the intensity and course of fungal spore seasons was verified.

\section{Materials and methods}

\subsection{Study area}

Research was conducted in south-eastern Poland, in Rzeszow $\left(50^{\circ} 02^{\prime} 28^{\prime \prime N}, 021^{\circ} 59^{\prime} 56^{\prime}\right.$ ) $)$, which is situated on Rzeszow Foothills at an altitude of $220 \mathrm{~m}$ a.s.l (Fig. 1).

Rzeszow's urban structure is characterized by large diversity (Borycka et al. 2017). The downtown area is a densely built-up area where blocks of flats, industrial and public buildings predominate. Greenery constitutes an important element of the urban fabric and 14 urban parks with a total area of 81.5 ha are an important part of it. The notable elements of the city's landscape are the Wisłok River and storage reservoir constructed on it. Great amount of agricultural land use (arable lands and pastures, meadows and orchards) is situated mainly in the suburbs. Rzeszow is located in the temperate warm climate zone. From 1997 to 2016, the annual rainfall was $692 \mathrm{~mm}$ and the annual temperature was $8.7^{\circ} \mathrm{C}$. The mean temperature in the coldest month, January, is $-2.0{ }^{\circ} \mathrm{C}$, and in the warmest month, July, it is $19.1{ }^{\circ} \mathrm{C}$ (Borycka et al. 2017). The research was carried out in 3 urban parks, diversified in terms of land management and other characteristics, that make them suitable to perform sampling: Park Zdrowia (P1), Park Jedności Polonii z Macierzą (P2) and Park Kultury i Wypoczynku (P3). On average, the distance between the parks is $2 \mathrm{~km}$ (Fig. 1). P1 is a peripheral park; P2 is a typically downtown park, located within dense buildings in the

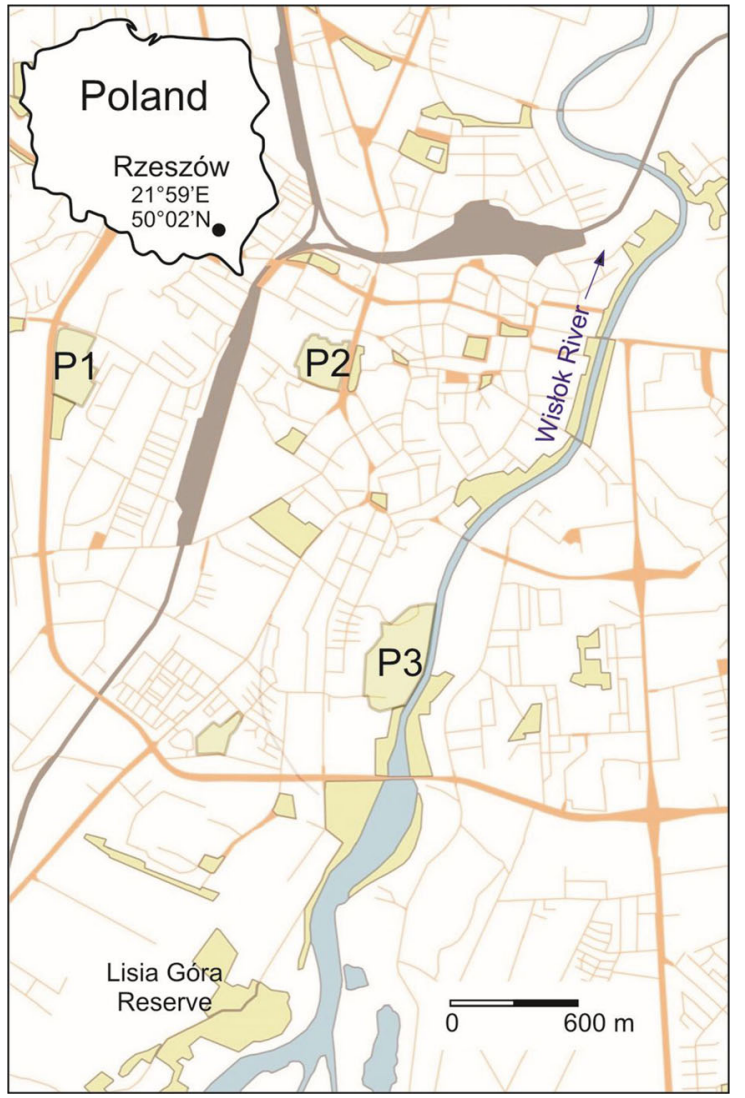

Fig. 1 Location of the parks under the study on the background of urban fabric

center of the city. P3 has a landscape character and is located in the river valley (Ćwik et al. 2018). The studied parks differ in terms of biodiversity, but in all native tree species predominate (mainly Acer platanoides, A. pseudoplatanus, Tilia cordata, T. platyphyllos, Betula pendula, Fraxinus excelsior), while shrub is mainly represented by ornamented varieties, often of foreign origin (Kasprzyk et al. 2019a). In contrast to P2 and P3, P1 is a park with the lowest biodiversity and the lowest number of tree species. $60 \%$ of its total area is covered by the canopy mainly Picea pungens, Tilia sp. and Acer sp. Compared to other Rzeszow parks, $\mathrm{P} 2$ has the most specimens of old trees and shrubs, which emphasizes its higher visual value. The canopy-covered area is $55 \%$ in average. This park is located in the city center. In P3, apart from hedges and larger groups of trees, solitary trees grow. This park has the lowest tree canopy and large open areas (Kasprzyk et al. 2019a). 


\subsection{Aerobiological monitoring}

Aerobiological monitoring was conducted from the beginning of April to the end of September 2016, during the season when climatic conditions are favorable for parks visiting. Samples (50 in each park) were taken in non-wooded areas without architectural barriers. There was no tree growing in each park within a $5 \mathrm{~m}$ radius of the measuring points. Fungal spores were sampled every 3-4 days (except rainy days) between $11 \mathrm{am}$ and $2 \mathrm{pm}$ (the time with maximum spores concentrations of many taxa and favorable for parks visits) using portable Burkard Personal Sampler at the height of app. $1 \mathrm{~m}$ a.g.l.. It had been working for $30 \mathrm{~min}$ in each park. Air (10 1 of air per minute) was sucked through a vertically orientated inlet directly on microscopic slide covered by Silicon medium. The cut-off size (collecting efficiency) of the Burkard sampler is $2.5 \mu \mathrm{m}$ particle diameter (Grinshpun et al. 2005). The slides were transported to the laboratory in a special box that prevents their destruction and contamination, and then covered by coverslide with glycerogelatin drops. The spores were identified and counted from $14 \mathrm{~mm}^{2}$ area of microscopic slide, what corresponds to the size of the rectangular inlet in the trap through which air was sucked. A light microscope at 400 or 600 magnification was used. The results were expressed as fungal spores concentration per $1 \mathrm{~m}^{3}$ of air at the time of measurement (see above, Galán et al. 2017). SSIn (Seasonal Spore Integral) was calculated by summing the concentration from 150 samples collected in the parks, the maximum concentration, days of maximum concentration, start and end of the period of occurrence in the air were presented for those fungal taxa that are allergenic and SSIn exceeded 100. The start and end of this period were defined as the first day and the last day of continuous occurrence on at least three days, respectively.

\subsection{Data analysis}

Biodiversity of fungal spore spectra was described by Shannon-Wiener index $\left(H^{\prime}\right)$. Synchronization of the occurrence of spores in the air was measured by means of Spearman rank correlation coefficient. This nonparametric test was chosen because the frequency distributions were not normal, which was confirmed by the Shapiro-Wilk test. The level of significance was selected at $\alpha \leq 0.05$. Relationships between parks and fungal spores were determined using Principal Component Analysis (PCA). The results were illustrated in a two-dimensional scatter plot. The analysis of the results was analyzed using PAST 3.0, Statistica 13 and Canoco 5 software.

\section{Results}

The quantitative and qualitative spectra of fungal spore are very similar in the studied park. In each park 27 out of 30 taxa were identified, and SSIn values ranged from 117,297 in $\mathrm{P} 2$ to 127,215 in $\mathrm{P} 1$. Cladosporium spores were present in the air in the highest level (above 105,000 on average), and then at much lower concentrations Leptosphaeria (4200 on average) and Alternaria (3400 on average), respectively (Fig. 2). While the percentage of Cladosporium spores in each park exceeded $85 \%$, in case of Leptosphaeria values ranged from $3.2 \%$ in $\mathrm{P} 1$ to $3.8 \%$ in $\mathrm{P} 3$ and for Alternaria from $2.5 \%$ in $\mathrm{P} 1$ to $2.9 \%$ in P2 and P3 (Table 1). Three taxa mentioned above achieved similar SSIn values in each park. Periconia, Polythrincium, Dreschlera and Paraphaeosphaeria also belong to this group of taxa; however, their concentrations were sometimes definitely lower than Cladosporium, e.g. Polythrincium in P2 (119) or Dreschlera type in P1 (115). The distinct differences between the parks concerned spore types which concentrations were extremely high or low in one park only. In the downtown P2 park, an unusually large amount of Ganoderma, Torula and Sporormiella was found comparing to the other; in P3 it concerned Epicoccum and Pithomyces spores. The diversity of fungal spores in the parks was relatively low, as testify by the values of the coefficient $H^{\prime}$ (Fig. 2).

Considering the 17 most common taxa, P1 and P2 parks have been shown to be very similar with the highest concentration of Cladosporium and Ganoderma spores. Higher concentrations of Alternaria, Epicoccum, Leptosphaeria, Periconia and Torula spores can be associated with P3 (Fig. 3).

Cladosporium spores were present in the air almost every day (turnout $98-100 \%$ ). A clear increase in concentrations has been observed since the beginning of June and the maximum concentration ranged from 11,550 spores in $1 \mathrm{~m}^{3}$ in $\mathrm{P} 1$ to 23,100 spores in $1 \mathrm{~m}^{3}$ in P3. It is worth emphasizing that the maximum 

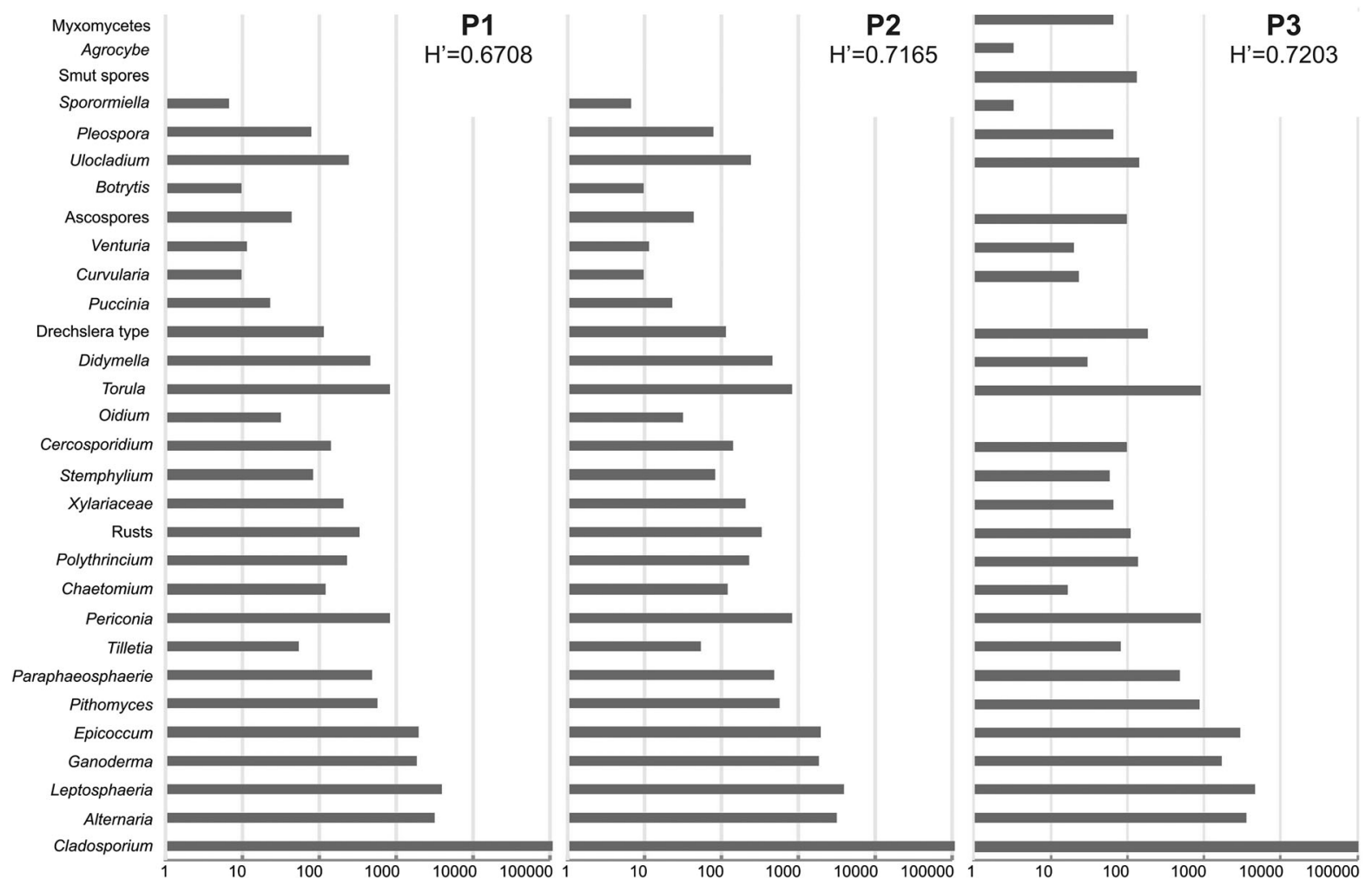

Fig. 2 SSIn of fungal spores recorded in the parks (P1-P3) with the biodiversity index H'

concentrations occurred on the same day, i.e. on July 18. Definitely lower concentrations were found in the case of Alternaria. Significant spore concentrations were found from the end of June to the second decade of September, and maximum at the turn of July and August. Spores of this type were present in the air with an $80-86 \%$ frequency (Table 1, Fig. 4). The occurrence periods of these allergenic spores coincided in each park with synchronization from $r=0.363572$ for Cladosporium and Epicoccum in P3 to $r=0.728060$ for Alternaria and Epicoccum in P2. In P1 and P2, the seasons of Ganoderma spores overlapped to a small extent and in park P3 the temporal synchronization of the spores occurrence in the air was not statistically significant. Regardless of the type of park, the high concentrations of Alternaria and Epicoccum occurred on a similar dates (Table 2).

Ganoderma spores were present in the air to a much lesser extent, and its percentage share in the total sum ranged from $1.4 \%$ in $\mathrm{P} 3$ to $2.1 \%$ in $\mathrm{P} 2$. The most spores were found in $\mathrm{P} 2$, but the maximum concentration was the lowest, with over 100 spores comparing to P1. Although the period of their continuous occurrence in
P1 and P3 began at the end of April or early May, the significant concentrations were recorded only from mid-July to the end of the monitoring period. At the turn of August and September maximum concentrations were obtained (Tables 1, 2, Fig. 4). The spore season of Ganoderma spores coincided only with the Alternaria season in $\mathrm{P} 1$ and $\mathrm{P} 2$, but synchronization of these seasons was poor (Table 2). Leptosphaeria spores have different seasonality. They occurred in the air irregularly with frequency about $68-74 \%$. In the warmest period, i.e. from mid-June to the beginning of August, the concentrations were clearly lower than in spring and late summer. Maximum concentrations were found in P1 and P2 on April 15 and in P3 on 6 September. The incidence of Epicoccum spores ranged from $76 \%$ in $\mathrm{P} 1$ to $84 \%$ in $\mathrm{P} 2$. The percentage SSIn was the highest for P3, and the highest concentration was almost 500 spores in $\mathrm{m}^{3}$, while in $\mathrm{P} 1$ and $\mathrm{P} 2347 \mathrm{in}^{3}$ and 172 in $\mathrm{m}^{3}$, respectively. Until midJune, spores appeared in low concentrations and their absence was often noted. As in the case of Alternaria, a significant an increase in concentrations occurred since mid-June and the seasons overlapped to a large 


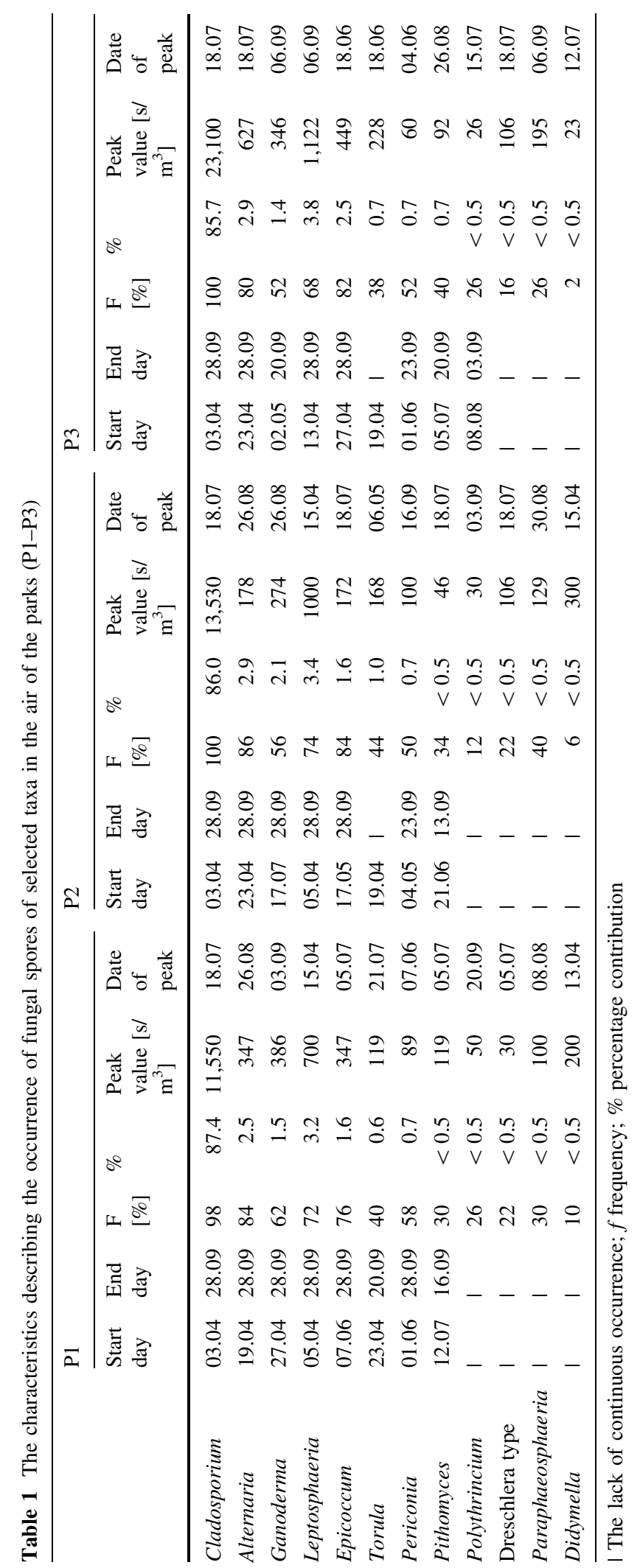




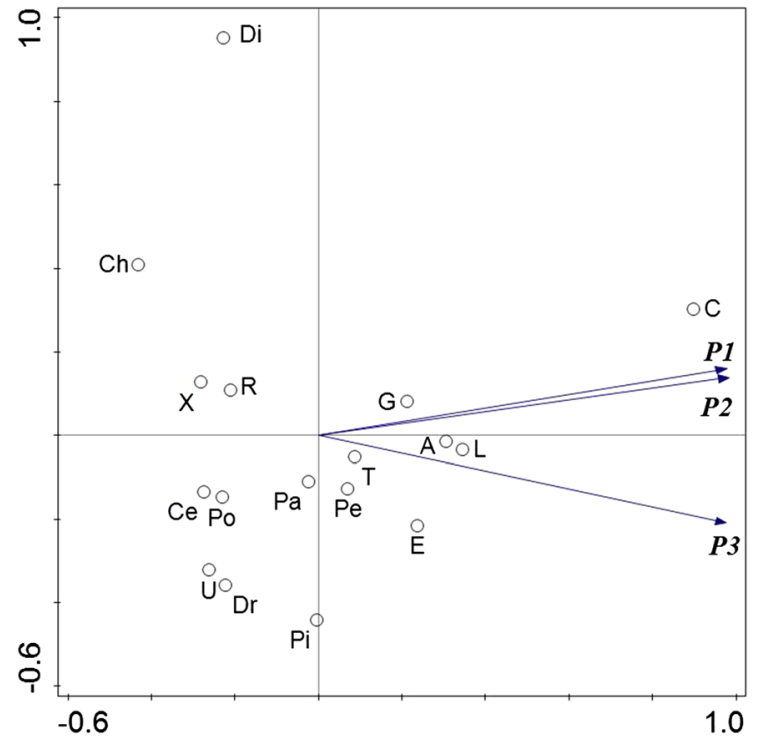

Fig. 3 A PCA scatterplot visualizing the relationship between parks and fungal taxa (A, Alternaria; C, Cladosporium; Ce, Cercosporidium; Di, Didimella; Dr, Dreschlera type; Ch, Chaetomium; E, Epicoccum; G, Ganoderma; L, Leptosphaeria; $\mathrm{Pa}$, Paraphaeosphaeria; Pi, Pithomyces; Po, Polythrincium; R, rusts; T, Torula; U, Ulocladium; X, Xylariaceae).

extent (Tables 1, 2, Fig. 4). Occurrence of Polythrincium, Dreschlera type, Paraphaeosphaeria and Didymella spores were very irregular; hence the continuous period of their presence in the air could not be determined. With the exception of Paraphaeosphaeria in $\mathrm{P} 2$, the incidence was less or equal to $30 \%$, extremely low in Didymella from $2 \%$ in P3 to $10 \%$ in P1. The percentages of these taxa in SSIn were very low, often $<0.5 \%$ (Table 1, Fig. 4 ).

The dynamics of occurrence of fungal spores represented in large numbers in the air was similar in each park. The highest similarities in the dynamics of the season, especially between P1 and P2, were found in the case of Cladosporium, Alternaria, Ganoderma, Epicoccum, Leptosphaeria and the lowest in the case of Torula and Dreschlera type. This is demonstrated by the values of the Spearman rank correlation coefficient illustrating the synchronization of the occurrence of spores in the air (Table 3).

\section{Discussion}

Park vegetation is a potential source of a huge number of airborne spores. Trees growing in parks are often infected by parasitic fungi. Saprophytic fungi, e.g. genera Epicoccum, Botrytis, Cladosporium, Alternar$i a$, develop on dead plant debris, causing decay and decomposition. Xylaria cause white rot, while soft rot is the result of Pleospora and Chaetomium (Srivatsava et al. 2013). Stemphylium botryosum, Pleospora platanoidesa parasite on maple samaras, and species from the genera Torula or Cladosporium on their leaves. Species of Ganoderma genus are parasites of deciduous trees and cause white rot of linden wood $(G$. lipense, G. adspersum) and maples (G. lucidum) (Grzywacz 1991, 1999). G. applanatum has the ability to degrade the heartwood and sapwood of broadleaved trees. In Honkong, like G. lucidum, it is considered a medium risk species (GLTMS 2019).

Spores of above-mentioned types were noted in the air of the parks studied. They are strong allergenic or their spores are considered as potentially allergenic (Green et al. 2005; Simon-Nobbe et al. 2008; Levetin et al. 2016); therefore, allergy sufferers should know their presence and concentrations in certain periods of the year so that they can take risk prevention measures. Literature data indicate that among the numerous allergenic fungal spores, the strongest airborne allergenic are those of the conidia as Alternaria, Cladosporium, Penicillium, Aspergillus and basidiospores such as Ganoderma, Chaetomium, Coprinus (Harvey 1970; Lehrer et al. 1994; Helbling et al. 1998; Hasnain et al. 2004; Fukutomi and Taniguchi 2015).

Cladosporium spores were found in enormous concentrations in all studied parks and it affected the low biodiversity of fungal aerosol in the studied parks. Fungi of this genus are cosmopolitan, ubiquitous organisms, grow on plant material, but have also been isolated from inorganic materials such as stones, bricks, window, plaster (Skóra et al. 2015). Spores of this type are a common cause of asthma and frequently induce type I allergy (Harvey 1970; Simon-Nobbe et al. 2008). Based on analyzes of the available literature Weryszko-Chmielewska et al. (2018) indicate that nearly twenty allergens have been isolated from spores of this type that occur in mycelium or conidia. Among Cladosporium species, C. herbarum is noticeable cause of fungal allergy. Fourteen allergens isolated from this species are known, but the main allergen is Clad $\mathrm{h} 8$. The monosensititation to this species is rare (Simon-Nobbe et al. 2008). Spores of this type pose a threat for allergenic people if the 

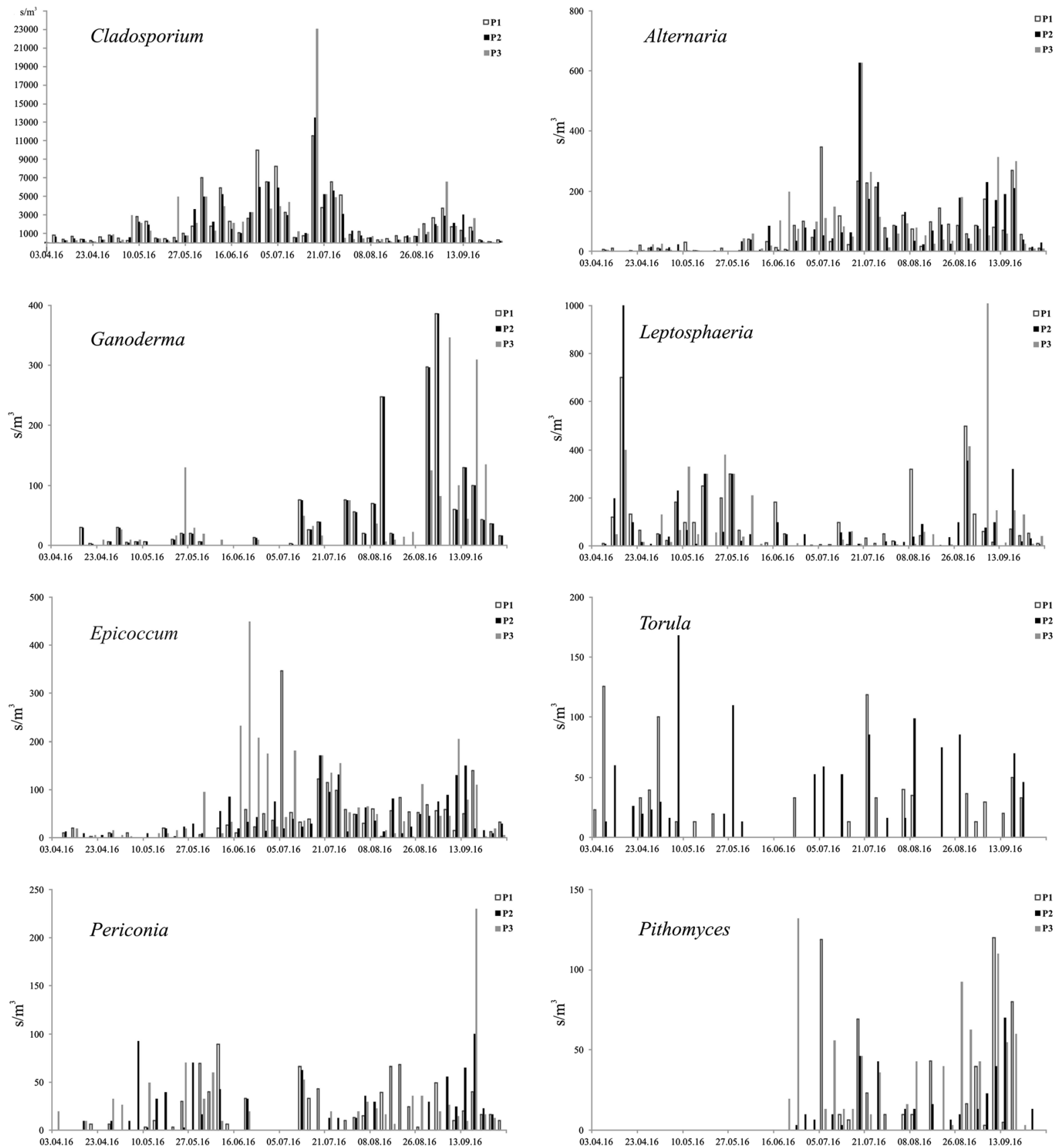

Fig. 4 Seasonal occurrence of airborne fungal spores of Alternaria, Cladosporium, Ganoderma, Leptosphaeria, Epicoccum, Torula, Priconia, Pithomyces in the parks P1-P3

mean daily concentration exceeds the threshold value. Weryszko-Chmielewska et al. (2018) pointed that different values are given in the literature-2800/ $3000 / 4000$ spores per $1 \mathrm{~m}^{3}$ of the air. The presented study indicates that on days when the weather is favorable for visiting the urban parks (days without rain) spores occurred in the air almost always, often at concentrations above the threshold value; hence they are a serious threat to park users.

Compared to Cladosporium, concentrations of other spores in the air were several dozen times lower, but still a risk for people who are allergic. Alternaria 
Table 2 Spearman's rank correlation coefficients as a measure of synchronization of the occurrence of allergenic fungal spores in the air of each park (P1-P3) separately

$N S$ not significant

\begin{tabular}{|c|c|c|c|c|}
\hline & Cladosporium & Alternaria & Epicoccum & Ganoderma \\
\hline \multicolumn{5}{|l|}{ P1 } \\
\hline Cladosporium & & 0.618338 & 0.437937 & NS \\
\hline Alternaria & 0.618338 & & 0.686090 & 0.298821 \\
\hline Ерісоссит & 0.437937 & 0.686090 & & NS \\
\hline Ganoderma & NS & 0.298821 & NS & \\
\hline \multicolumn{5}{|l|}{ P2 } \\
\hline Cladosporium & & 0.560168 & 0.514447 & NS \\
\hline Alternaria & 0.560168 & & 0.728060 & 0.457045 \\
\hline Eрісоссит & 0.514447 & 0.728060 & & NS \\
\hline Ganoderma & NS & 0.457045 & NS & \\
\hline \multicolumn{5}{|l|}{ P3 } \\
\hline Cladosporium & & 0.646950 & 0.363572 & NS \\
\hline Alternaria & 0.646950 & & 0.592511 & NS \\
\hline Epicoccum & 0.363572 & 0.592511 & & NS \\
\hline Ganoderma & NS & $\mathrm{NS}$ & NS & \\
\hline
\end{tabular}

or Epicoccum will be higher. In fact, in September only the Epicoccum concentration increased, compared to the full vegetation period. The sensitivity to Epicoccum purpurarescens is estimated on the level of 5 to $7 \%$ in human population (Bisht et al. 2004).

Ganoderma is a genus from the group of basidiomycetes, a fungus that colonizes trees or dead wood. In Poland its fungal atmospheric season overlaps with those of Alternaria and Cladosporium what increases additional danger for sensitized people (Grinn-Gofron 2010). Spores occur most frequently in the downtown park, where the stand is the oldest and richness of species dendroflora the largest (Kasprzyk et al. 2019a). During the inventory of the stand in each park, it was not found that the trees were attacked by Ganoderma. The Ganoderma example indicates that even high spore concentrations may not be the result of in situ production. Because of small size, the spores can easily travel long distances; hence, the spatial variation in their concentration is not necessarily due to the abundance of local spore sources.

A high proportion of allergic patients is polysensitized; react to allergens of various fungi, pollen and even food (Twaroch et al. 2015). We show dangerous situations: high or very high concentrations of Cladosporium and Alternaria near ground level, the most frequently sensitizing fungal spores, as well as Epicoccum, less likely to cause allergies, occurred at the same time (the second half of July). In temperate climates it is also a period when high concentrations of 
Table 3 Spearman's rank correlation coefficients as a measure of synchronization of fungal spores seasons in the parks (P1-P3)

$N S$ not significant

\begin{tabular}{|c|c|c|c|c|c|c|c|}
\hline & \multicolumn{3}{|c|}{ Cladosporium } & & \multicolumn{3}{|l|}{ Alternaria } \\
\hline & $\mathrm{P} 1$ & $\mathrm{P} 2$ & P3 & & $\mathrm{P} 1$ & $\mathrm{P} 2$ & P3 \\
\hline P1 & & 0.942843 & 0.660510 & P1 & & 0.843842 & 0.685768 \\
\hline $\mathrm{P} 2$ & \multicolumn{2}{|l|}{0.942843} & 0.692535 & $\mathrm{P} 2$ & \multicolumn{2}{|l|}{0.843842} & 0.740675 \\
\hline \multirow[t]{3}{*}{ P3 } & 0.660510 & 0.692535 & & P3 & 0.685768 & 0.740675 & \\
\hline & \multicolumn{3}{|l|}{ Ganoderma } & & \multicolumn{3}{|c|}{ Leptosphaeria } \\
\hline & $\mathrm{P} 1$ & $\mathrm{P} 2$ & P3 & & $\mathrm{P} 1$ & $\mathrm{P} 2$ & P3 \\
\hline P1 & & 0.614071 & 0.589896 & $\mathrm{P} 1$ & & 0.620870 & 0.443400 \\
\hline $\mathrm{P} 2$ & 0.614071 & & 0.527166 & $\mathrm{P} 2$ & 0.620870 & & 0.613187 \\
\hline \multirow[t]{3}{*}{ P3 } & 0.589896 & 0.527166 & & P3 & 0.443400 & 0.613187 & \\
\hline & \multicolumn{3}{|l|}{ Epicoccum } & & \multicolumn{2}{|c|}{ Torula } & \\
\hline & $\mathrm{P} 1$ & $\mathrm{P} 2$ & P3 & & $\mathrm{P} 1$ & $\mathrm{P} 2$ & P3 \\
\hline P1 & & 0.637100 & 0.589239 & $\mathrm{P} 1$ & & NS & 0.282109 \\
\hline $\mathrm{P} 2$ & 0.637100 & & 0.538504 & $\mathrm{P} 2$ & NS & & NS \\
\hline \multirow[t]{3}{*}{ P3 } & 0.589239 & 0.538504 & & $\mathrm{P} 3$ & 0.282 & NS & \\
\hline & \multicolumn{3}{|l|}{ Periconia } & & \multicolumn{3}{|c|}{ Pithomyces } \\
\hline & $\mathrm{P} 1$ & $\mathrm{P} 2$ & P3 & & $\mathrm{P} 1$ & $\mathrm{P} 2$ & P3 \\
\hline P1 & & NS & 0.414494 & $\mathrm{P} 1$ & & 0.406733 & 0.542044 \\
\hline $\mathrm{P} 2$ & NS & & 0.290427 & $\mathrm{P} 2$ & 0.406733 & & 0.484412 \\
\hline \multirow[t]{3}{*}{ P3 } & 0.414494 & 0.290427 & & $\mathrm{P} 3$ & 0.542044 & 0.484412 & \\
\hline & \multicolumn{3}{|c|}{ Polythrincium } & & \multicolumn{3}{|c|}{ Dreschlera type } \\
\hline & $\mathrm{P} 1$ & $\mathrm{P} 2$ & P3 & & P1 & P2 & P3 \\
\hline $\mathrm{P} 1$ & & 0.563628 & NS & $\mathrm{P} 1$ & & NS & NS \\
\hline $\mathrm{P} 2$ & 0.563628 & & NS & $\mathrm{P} 2$ & NS & & 0.346175 \\
\hline \multirow[t]{3}{*}{ P3 } & NS & NS & & $\mathrm{P} 3$ & NS & 0.346175 & \\
\hline & \multicolumn{3}{|c|}{ Paraphaeosphaeria } & & \multicolumn{3}{|l|}{ Didymella } \\
\hline & $\mathrm{P} 1$ & P2 & P3 & & $\mathrm{P} 1$ & $\mathrm{P} 2$ & P3 \\
\hline P1 & & 0.312916 & NS & $\mathrm{P} 1$ & & 0.503526 & NS \\
\hline $\mathrm{P} 2$ & 0.312916 & & 0.570654 & $\mathrm{P} 2$ & 0.503526 & & 0.386483 \\
\hline P3 & NS & 0.570654 & & P3 & NS & 0.386483 & \\
\hline
\end{tabular}

grass and mugwort pollen are found in the air (Myszkowska et al. 2011; Kasprzyk et al. 2019b). Grinn-Gofron et al. (2011) and Grewling et al. (2019) observed the dangerous phenomenon of co-occurrence of high concentrations of allergenic Alternaria spores and chemical air pollution ozone such as $\mathrm{CO}, \mathrm{PM}_{10}$. In general, air quality of the study area is good, the concentrations of chemical pollutants rarely exceed threshold values (WIOŚ 2019) in contrast to biological pollutants such as allergenic plant pollen and fungal spores what was previously documented by Kasprzyk et al. (2004), Borycka et al. (2017), WeryszkoChmielewska et al. (2018) and Kasprzyk et al. (2019b). It should be emphasized that in Rzeszów, the spores concentrations measured near the ground in urban parks were often higher than those measured at the roof level (Kasprzyk et al. 2004; Kasprzyk and Worek 2006; Weryszko-Chmielewska et al. 2018). 
The degree of danger for some allergenic spores differed, but it is difficult to define these differences by the type of vegetation (predominance of lawns/ predominance of trees) or park development. Considering the course of diurnal concentrations, it can be stated that the landscape type park (P3) stands out significantly because lawns predominate in the greenery type. For most taxa in this park, the similarity of the airborne spores occurrence season was smaller, compared to other parks which is clearly seen in the case of Epicoccum and Pithomyces. Park vegetation may or may not be the source of a huge number of spores. It undergoes intensive care (e.g. removal of withered branches, raking litter) limiting the development of mycelium and the production of spores. Studies show that some spores occur exceptionally abundant in each park regardless of its nature and vegetation. The dynamics of airborne spores presence in the air of all parks is more or less synchronized, which may mean that their sources of emissions are in the surrounding environment, that is, in the vegetation making up the park.

\section{Conclusions}

Despite the fact that fungal spores are always present in the air of everywhere, urban parks represent a very suitable environment so that the presence of fungal spores is high or very high regardless of the type of park (landscape, peripheral or downtown park). However, the landscape-type urban park differs from the remaining in terms of fungal spores spectrum. Impact of potential factors on this phenomenon, such as structure of land cover or the location near the river forcing air movement along its riverbed, requires a further study.

The greatest threat for allergy sufferers is the period when the most allergenic spores, Cladosporium, Alternaria, occur at the same time. In temperate climate this is July-August. In this period also strongly allergenic grass and mugwort pollen dominates in the air, what creates an additional risk for allergic people. Therefore, despite the fact that parks improve urban microclimate allergenic people should limit their rest there during summer. This study highlights that urban parks can be an important source of fungal allergens and therefore need to be considered when establishing the risk this may pose for allergy patients.
Open Access This article is licensed under a Creative Commons Attribution 4.0 International License, which permits use, sharing, adaptation, distribution and reproduction in any medium or format, as long as you give appropriate credit to the original author(s) and the source, provide a link to the Creative Commons licence, and indicate if changes were made. The images or other third party material in this article are included in the article's Creative Commons licence, unless indicated otherwise in a credit line to the material. If material is not included in the article's Creative Commons licence and your intended use is not permitted by statutory regulation or exceeds the permitted use, you will need to obtain permission directly from the copyright holder. To view a copy of this licence, visit http://creativecommons.org/licenses/by/4.0/.

\section{References}

Bisht, V., Arora, N., Singh, B. P., Gaur, S. N., \& Sridhara, S. (2004). Purification and characterization of a major crossreactive allergen from Epicoccum purpurascens. International Archives of Allergy and Immunology, 133(3), 217-224. https://doi.org/10.1159/000076827

Borycka, K., Ortyl, B., \& Kasprzyk, I. (2017). Temporal variation and spatial differentiation of black alder and silver birch pollination course-an impact of local climate or something more? Agricultural and Forest Meteorology, 247, 65-78. https://doi.org/10.1016/j.agrformet.2017.07. 017

Budd, T. W. (1986). Allergens of Alternaria. Grana, 25, 147-154. https://doi.org/10.1080/00173138609428895

Bush, R. K., \& Prochnau, J. J. (2004). Alternaria-induced asthma. The Journal of Allergy and Clinical Immunology, 113(2), 227-234. https://doi.org/10.1016/j.jaci.2003.11. 023

Chew, F. T., Lim, S. H., Shang, H. S., Dahlia, M. D., Goh, D. Y., Lee, B. W., et al. (2000). Evaluation of the allergenicity of tropical pollen and airborne spores in Singapore. Allergy, 55(4), 340-347. https://doi.org/10.1034/j.1398-9995.2000. 00308.x

Ćwik, A., Kasprzyk, I., Wójcik, T., Borycka, K., \& Cariñanos, P. (2018). Attractiveness of urban parks for visitors versus their potential allergenic hazard: A case study in Rzeszów, Poland. Urban Forestry \& Urban Greening, 35, 221-229. https://doi.org/10.1016/j.ufug.2018.09.009

Dales, R. E., Cakmak, S., Burnett, R. T., Judek, S., Coates, F., \& Brook, J. R. (2000). Influence of ambient fungal spores on emergency visits for asthma to a regional children's hospital. American Journal of Respiratory and Critical Care Medicine, 162, 2087-2090. https://doi.org/10.1164/ ajrccm.162.6.2001020

Damialis, A., Mohammad, A. B., Halley, J. M., \& Gange, A. C. (2015). Fungi in a changing world: Growth rates will be elevated, but spore production may decrease in future climates. International Journal of Biometeorology, 59(9), 1157-1167. https://doi.org/10.1007/s00484-014-0927-0

Fukutomi, Y., \& Taniguchi, M. (2015). Sensitization to fungal allergens: Resolved and unresolved issues. Allergology International, 64(9), 321-331. https://doi.org/10.1016/j. alit.2015.05.007 
Galán, C., Ariatti, A., Bonini, M., Clot, B., Crouzy, B., Dahl, A., et al. (2017). Recommended terminology for aerobiological studies. Aerobiologia, 33, 293-295.

GLTMS (Greening, landscape \& tree management section, development bureau, the government of the Hong Kong special administrative region of the People's Republic of China) .(2019). Retrieved September 23, 2019, from https://www.greening.gov.hk/en/home/index.html.

Green, B. J., Sercombe, J. K., \& Tovey, E. R. (2005). Fungal fragments and undocumented conidia function as new aeroallergen sources. The Journal of Allergy and Clinical Immunology, 115(5), 1043-1048. https://doi.org/10.1016/ j.jaci.2005.02.009

Grewling, Ł, Nowak, M., Szymańska, A., Kostecki, Ł, \& Bogawski, P. (2019). Temporal variability in the allergenicity of airborne Alternariaspores. Medical Mycology, 57(4), 403-411. https://doi.org/10.1093/mmy/myy069

Grinn-Gofron, A. (2010). The occurrence of Ganoderma spores in the air and its relationships with meteorological factors. Acta Agrobotanica, 63(1), 93-97. https://doi.org/10.5586/ aa.2010.011

Grinn-Gofroń, A., Strzelczak, A., \& Wolski, T. (2011). The relationships between air pollutants, meteorological parameters and concentration of airborne fungal spores. Environmental Pollution, 159(2), 602-608. https://doi.org/ 10.1016/j.envpol.2010.10.002

Grinshpun, S. A., Mainelis, G., Trunov, M., Górny, R. L., Sivasubramani, S., Adhikari, A., \& Reponen, T. (2005). Collection of airborne spores by circular single-stage impactors with small jet-to-plate distance. Journal of Aerosol Science, 36, 575-591.

Grzywacz, A. (1991). More important infectious diseases. In S. Białobok (Ed.), Limes (pp. 277-318). Poznań: PAN, Instytut Dendrologii.

Grzywacz, A. (1999). More important infectious diseases. In W. Bugała (Ed.), Maples (pp. 427-469). Poznań: PAN, Instytut Dendrologii.

Harvey, R. (1970). Spore productivity in Cladosporium. Mycopathologia et Mycologia Applicata, 41, 251-256. https:// doi.org/10.1007/BF02051103

Hasnain, S. M., Al-Frayh, A., Khatija, F., \& Al-Sedairy, S. (2004). Airborne Ganoderma basidiospores in a country with desert environment. Grana, 43, 111-115. https://doi. org/10.1080/00173130410019613

Heinzerling, L. M., Burbach, G. J., Edenharter, G., Bachert, C., Bindslev-Jensen, C., Bonini, S., et al. (2009). GA (2) LEN GA2LEN harmonization of skin prick testing: Novel sensitization patterns for inhalant allergens in Europe. Allergy, 64(10), 1498-1506. https://doi.org/10.1111/j.1398-9995. 2009.02093.x

Helbling, A., Gayer, F., Pichler, W. J., \& Brander, K. A. (1998). Mushroom (Basidiomycete) allergy: Diagnosis established by skin test and nasal challenge. The Journal of Allergy and Clinical Immunology, 102(5), 853-858. https://doi.org/10. 1016/S0091-6749(98)70028-4

Jędryczka, M., Sadyś, M., Gilski, M., Grinn-Gofroń, A., Kaczmarek, J., Strzelczak, A., et al. (2016). Contribution of Leptosphaeria species ascospores to autumn asthma in areas of oilseed rape production. Annales of Allergy, Asthma \& Immunology, 117(5), 495-501. https://doi.org/ 10.1016/j.anai.2016.08.027
Kasprzyk, I., Ćwik, A., Kluska, K., Wójcik, T., \& Cariñanos, P. (2019). Allergenic pollen concentrations in the air of urban parks in the relation to their vegetation. Urban Forestry \& Urban Greening, 46, 126486. https://doi.org/10.1016/j. ufug.2019.126486

Kasprzyk, I., Rzepowska, B., \& Wasylów, M. (2004). Fungal spores in the atmosphere of Rzeszów (South-East Polad). Annales of Agricultural and Environmental Medicine, 11(2), 285-289.

Kasprzyk, I., Wójcik, T., Cariñanos, P., Borycka, K., \& Ćwik, A. (2019). Evaluation of allergenicity of various types of urban parks in a warm temperate climate zone. Aerobiologia, 35(1), 57-71. https://doi.org/10.1007/s10453-0189537-3

Kasprzyk, I., \& Worek, M. (2006). Airborne fungal spores in urban and rural environments in Poland. Aerobiologia, 22, 169-176. https://doi.org/10.1007/s10453-006-9029-8

Knutsen, A. P., Bush, R. K., Demain, J. G., Denning, D. W., Dixit, A., Fairs, A., et al. (2012). Fungi and allergic lower respiratory tract diseases. The Journal of Allergy and Clinical Immunology, 129(2), 280-291. https://doi.org/10. 1016/j.jaci.2011.12.970

Konijnendijk, C. C. (2018). The forest and the city. The cultural landscape of urban Woodland. Cham: Springer International Publishing.

Lee, S. A., \& Liao, C. H. (2014). Size-selective assessment of agricultural workers' personal exposure to airborne fungi and fungal fragments. Science of the Total Environment, 466-467, 725-732. https://doi.org/10.1016/j.scitotenv. 2013.07.104

Lehrer, S. B., Hughes, J. M., Altman, L. C., Bousquet, J., Davies, R. J., Gell, L., et al. (1994). Prevalence of basidiomycete allergy in the USA and Europe and its relationship to allergic respiratory symptoms. Allergy, 49(6), 460-465. https://doi.org/10.1111/j.1398-9995.1994. tb00840.x

Levetin, E. (1991). Identification and concentration of airborne basidiospores. Grana, 30, 123-128. https://doi.org/10. 1080/00173139109427785

Levetin, E., Horner, W., \& Scott, J. A. (2016). Taxonomy of allergenic fungi. The Journal of Allergy and Clinical Immunology: In Practice, 4(3), 375-385. https://doi.org/ 10.1016/j.jaip.2015.10.012

Masoli, M., Fabian, D., Holt, S., \& Beasley, R. (2004). The global burden of asthma: Executive summary of the GINA dissemination committee report. Allergy, 59(5), 469-478. https://doi.org/10.1111/j.1398-9995.2004.00526.x

Mitakakis, T. Z., Barnes, C., \& Tovey, E. R. (2001). Spore germination increases allergen release from Alternaria. The Journal of Allergy and Clinical Immunology, 107(2), 388-390. https://doi.org/10.1067/mai.2001.112602

Myszkowska, D., Jenner, B., Stępalska, D., \& Czarnobilska, E. (2011). The pollen season dynamics and the relationship among some season parameters (start, end, annual total, season phases) in Kraków, Poland, 1991-2008. Aerobiologia, 27(3), 229-238. https://doi.org/10.1007/s10453010-9192-9

Olsen, Y., Gosewinkel, U. B., Skjøth, C. A., Hertel, O., Rasmussen, K., \& Sigsgaard, T. (2019). Regional variation in airborne Alternaria spore concentrations in Denmark through 2012-2015 seasons: The influence of meteorology 
and grain harvesting. Aerobiologia, 35(3), 533-551. https://doi.org/10.1007/s10453-019-09587-x

Selgrade, M. K., Lemanske, R. F., Gilmour, M. I., Neas, L. M., Ward, M. D. W., Henneberger, P. K., et al. (2006). Induction of asthma and the environment: What we know and need to know. Environmental Health Perspectives, 114(4), 615-619. https://doi.org/10.1289/ehp.8376

Seto, K. C., Fragkias, M., Güneralp, B., \& Reilly, M. K. (2011). A meta-analysis of global urban land expansion. PLoS ONE, 6(8), e23777. https://doi.org/10.1371/journal.pone. 0023777

Simon-Nobbe, B., Denk, U., Poll, V., Rid, R., \& Breitenbach, M. (2008). The spectrum of fungal allergy. International Archives of Allergy and Immunology, 145(1), 58-86. https://doi.org/10.1159/000107578

Singh, A. B., \& Mathur, C. (2012). An aerobiological perspective in allergy and asthma. Asia Pacific Allergy, 2(3), 210-222. https://doi.org/10.5415/apallergy.2012.2.3.210

Skjøth, C. A., Damialis, A., Belmonte, J., De Linares, C., Fernández-Rodríguez, S., Grinn-Gofroń, A., et al. (2016). Alternaria spores in the air across Europe: Abundance, seasonality and relationships with climate, meteorology and local environment. Aerobiologia, 32(1), 3-22. https:// doi.org/10.1007/s10453-016-9426-6

Skóra, J., Gutarowska, B., Pielech-Przybylska, K., Stępień, Ł, Pietrzak, K., Piotrowska, M., et al. (2015). Assessment of microbiological contamination in the work environments of museums, archives and libraries. Aerobiologia, 31(3), 389-401. https://doi.org/10.1007/s10453-015-9372-8

Srivatsava, S., Kumar, R., \& Singh, V. P. (2013). Wood decaying fungi. New Delhi: LAP LAMBERT Academic Publishing.
Tariq, S. M., Matthews, S. M., Stevens, M., \& Hakim, E. A. (1996). Sensitization to Alternaria and Cladosporium by the age of 4 years. Clinical \& Experimental Allergy, 26(7), 794-798. https://doi.org/10.1111/j.1365-2222.1996. tb00610.x

To, T., Stanojevic, S., Moores, G., Gershon, A. S., Bateman, E. D., Cruz, A. A., et al. (2012). Global asthma prevalence in adults: findings from the cross-sectional world health survey. BMC Public Health, 12, 204. https://doi.org/10.1186/ 1471-2458-12-204

Twaroch, T. E., Curin, M., Sterflinger, K., Focke-Tejkl, M., Swoboda, I., \& Valenta, R. (2016). Specific antibodies for the detection of Alternaria allergens and the identification of cross-reactive antigens in other fungi. International Archives Allergy Immunology, 170(4), 269-278. https:// doi.org/10.1159/000449415

Twaroch, T. E., Curin, M., Valenta, R., \& Swoboda, I. (2015). Mold allergens in respiratory allergy: From structure to therapy. Allergy, Asthma \& Immunology Research, 7(3), 205-220. https://doi.org/10.4168/aair.2015.7.3.205

Weryszko-Chmielewska, E., Kasprzyk, I., Nowak, M., Suliborska, A., Kaczmarek, J., Szymańska, A., et al. (2018). Health hazard caused by conidiospores of Cladosporiumbiological air pollutants in Poland, central Europe. Journal of Environmental Sciences, 65, 271-281. https://doi.org/ 10.1016/j.jes.2017.02.018

WHO (World Health Organization). (2019). Retrieved September 23, 2019, from https://www.who.int/ respiratory/asthma/en/.

WIOŚ (Wojewódzki Inspektorat Ochrony Środowiska w Rzeszowie, System monitoringu jakości powietrza) (2019). Retrieved September 23, 2019, from https://stacje.wios. rzeszow.pl/dane-pomiarowe/automatyczne. 